Creative Commons User License: CC BY-NC-ND

Abstracted by: EBSCOhost, Electronic Journals Service (EJS),

Google Scholar, Journal Seek, Scientific Commons,

Food and Agricultural Organization (FAO), CABI and Scopus
Journal of Agricultural Extension

Vol. 23 (4) October, 2019

ISSN(e): 24086851; ISSN(Print); 1119944X

http://journal.aesonnigeria.org

http://www.ajol.info/index.php/jae

Email: editorinchief@aesonnigeria.org

\title{
Farmers' Perceived Effects of Communal Conflicts on the Delivery of Agricultural Extension Services in North-Central, Nigeria \\ https://dx.doi.org/10.4314/jae.v23i4.5
}

\section{Adzenga Jacobs lor}

Department of Agricultural Extension and Economics, National Agricultural Extension and

Research Liaison Services (NAERLS), Ahmadu Bello University, P.M.B 1067, Zaria, Kaduna State, Nigeria

\section{Umar Isah Sheshi}

Department of Agricultural Extension and Rural Development, Federal University of Technology, Minna, Nigeria

\section{Olaleye Rotimi Saka}

Department of Agricultural Extension and Rural Development, Federal University of Technology, Minna, Nigeria

\section{Ajayi Oladipo Joseph}

Department of Agricultural Extension and Rural Development, Federal University of Technology, Minna, Nigeria

Onyenkazi Hycinth A.

Extension and Outreach Department, National Cereals Research Institute Badeggi, Niger State ${ }^{*}$ Corresponding Author: jacobior@yahoo.com 08069249529

\section{Abstract}

The study examined the perceived effects of communal conflicts on the delivery of agricultural extension services to farmers in North-central, Nigeria. The specific objectives were to; describe the socio-economic characteristics of the farmers; determine the perceived effects of communal conflicts on the delivery of agricultural extension services by field extension workers of Agricultural Development Programmes (ADPs) to farmers in the study area, and; identify the relationships between selected socio-economic characteristics and perceived effects of communal conflicts on agricultural extension services delivery. A multi-stage sampling technique was used to obtain a sample size of 391 farmers. Information was elicited using questionnaire, interview schedule and focus group discussion and analysed using frequencies, percentages, mean and Likert-type rating scale and Ordered Logit Regression analysis. The major findings show that the majority of the respondents in the study area perceived communal conflicts to have high effects on accessibility of extension services $(\bar{x}=2.50)$, timeliness of extension services ( $\bar{x}=2.49)$, efficiency of extension services $(\bar{x}$ $=2.49$ ), targeting of extension services ( $\bar{x}=2.48)$, effectiveness of extension services $(\bar{x}=2.41)$, relevance of extension services $(\bar{x}=2.36)$ and content accuracy of extension services $(\bar{x}=2.27)$. The findings 
Creative Commons User License: CC BY-NC-ND

Abstracted by: EBSCOhost, Electronic Journals Service (EJS),

Google Scholar, Journal Seek, Scientific Commons,

Food and Agricultural Organization (FAO), CABI and Scopus
Journal of Agricultural Extension

Vol. 23 (4) October, 2019

ISSN(e): 24086851; ISSN(Print); 1119944X

http://journal.aesonnigeria.org

http://www.ajol.info/index.php/jae

Email: editorinchief@aesonnigeria.org

http://eoi.citefactor.org/10.11226/v23i4

further reveal that sex of the farmers, marital status, educational level, number of extension contacts, farm size and distance from the farming communities to a major town had significant relationships with perceived effects of communal conflicts on extension services delivery. The study recommended that government should adopt policies that would tackle the causes and occurrence of communal conflicts in communities in the country so as to reduce the effect of the conflicts on timeliness, effectiveness, efficiency, targeting and usefulness of extension services.

Key words: Communal conflicts, extension services, farmers

\section{Introduction}

Conflicts over access to land continue to perpetuate poverty among famers and hinder agricultural development and food security in Nigeria (Bruce and Boudreaux, 2013). Chikaire, Orusha, Irebuisi, Amanze and Asonye (2016) revealed that communal conflicts have very serious effect on agricultural output, prices of produce, marketing and distribution of agricultural products, agricultural extension activities, agricultural credit opportunities, transportation costs, labour supply and farm income of farmers. Various factors have been identified as responsible for communal conflicts in the country depending on the socioeconomic and geopolitical circumstances at the time. Generally, Alimba (2014) identified economic, social, political, ecological and colonial factors as the underlying causes of communal conflicts in Nigeria.

Robertson and Steve (2012) reported that incessant resource-based conflicts have adversely affected the effective delivery of extension services by extension agents, which in turn reduced farmers' level of utilization of technologies in the area. The authors further stated that extension agents are hindered by conflicts of various magnitudes which make it difficult to carry out extension services like the number of visits per extension agent, number of contact with farmer groups, training of contact farmers and demonstrations on small plots or management training plots (MTPs) to teach the farmer new techniques and practices which enable them to compare the results of the old and new practices were greatly affected during conflict situation. In a similar development, Adelakun, Adurogbangba, and Akinbile (2015) indicated that the effect of conflict on availability of extension services, adoption of improved technologies by both crop and livestock farmers and continued use of adopted technologies was very severe. Kimenyi, Adibe, Djiré, Jirgi, Kergna, Deressa, Pugliese, and Westbury (2014) stated that agricultural extension agencies and institutions like the Agricultural Development Programmes (ADPs) and research institutes that support the agricultural sector are also affected during the conflict situations. Conflicts may have forced most of these institutions (government agencies, ADPs and research institutes) to reduce their activities like field trials and monitoring among others to minimal functions, relocate to areas where attacks are minimal or cancelled some activities.

A study conducted by Mercy Corps (2015) revealed that Nigeria stands to gain up to 13.7 billion US Dollars annually if a scenario of peace is maintained within the communities in Benue, Kaduna, Nasarawa, and Plateau States alone. The study further showed that States affected by communal conflicts loss an average of 47percent in internally generated revenue 
Creative Commons User License: CC BY-NC-ND

Abstracted by: EBSCOhost, Electronic Journals Service (EJS),

Google Scholar, Journal Seek, Scientific Commons,

Food and Agricultural Organization (FAO), CABI and Scopus
Journal of Agricultural Extension

Vol. 23 (4) October, 2019

ISSN(e): 24086851; ISSN(Print); 1119944X

http://journal.aesonnigeria.org

http://www.ajol.info/index.php/jae

Email: editorinchief@aesonnigeria.org

(IGR) through taxes due to these conflicts. Average households affected by conflicts would also experience at least a 64percent increase in income and potentially higher increase in income under a peaceful atmosphere. These conflicts have become endemic in Nigeria particularly in States like Plateau, Nasarawa, Benue, Taraba, Adamawa, Kaduna, Zamfara, Ekiti, Ogun, Ondo and Cross-Rivers amongst others. Many lives have been lost including livestock and crops worth millions of naira as well as disruption of essential services in the affected areas (Turkur, 2014).

Considering the effects of communal conflicts on the people and their farms, it becomes clear that once the farmers are displaced and their land abandoned, the agricultural extension services delivery which is an important aspect of agricultural production may also be affected. The extension field workers are left with a critical decision regarding their job and loyalty to the communities, villages and individuals who are in conflict areas where they operate (Robertson, 2013).

\section{Purpose of the Study}

The aim of the study was to ascertain the extent to which communal conflicts were perceived to affect agricultural extension service delivery in Benue and Nasarawa States, Nigeria. The specific objectives of the study were to:

i. determine the perceived effects of communal conflicts on the delivery of agricultural extension services by field extension workers of ADPs to farmers in the study area.

\section{Hypothesis of the Study}

Ho1. There is no significant relationship between selected socio-economic characteristics of the farmers and perceived effects of communal conflicts on agricultural extension services delivery.

\section{Methodology}

North Central Zone occupies total land area of $296,898 \mathrm{~km}^{2}$ representing about $32 \%$ of the land area of the country. It is located between latitudes $6^{\circ} 30^{\prime}$ to $11^{\circ} 20^{\prime}$ North and longitudes $2^{0} 30^{\prime}$ to $10^{\circ} 30^{\prime}$ East. More than $77 \%$ of the people in the region are mostly engaged in one form of agricultural activity or the other. The Zone has two main seasons namely dry and wet seasons, with the wet season beginning towards the end of March and ending at the end of October, while the dry season is from November to March. The rainfall per annum ranges from 1000 to $1500 \mathrm{~mm}$ with an average of 187 to 220 rainy days, and average monthly temperature ranging from $21^{\circ} \mathrm{C}$ and $37^{\circ} \mathrm{C}$. The vegetation of the Zone consists of the Forest Savannah Mosaic, Southern Guinea Savannah and the Northern Guinea Savannah (Ojo, Ojo, Odine, and Ogaji, 2014).). Geographically, varying landforms characterize Middle Belt Zone such as extensive and swampy feature that are common in the lowland areas which occur in the areas along the valleys of Niger and Benue rivers, deep, large hills, mountains and plateau. The vegetation, soil and weather patterns are favourable to produce a wide spectrum of agricultural food, industrial and cash crops of various types such as rice, yam, cassava, soybeans, millet, cowpea and maize (Tsado, 2013).

Purposive sampling was adopted to select two states (Benue and Nasarawa) from the seven states in North-central Nigeria where communal conflicts occur frequently. The population of the study comprised all farm families in Benue and Nasarawa States, Nigeria. All the 
Creative Commons User License: CC BY-NC-ND

Abstracted by: EBSCOhost, Electronic Journals Service (EJS),

Google Scholar, Journal Seek, Scientific Commons,

Food and Agricultural Organization (FAO), CABI and Scopus
Journal of Agricultural Extension

Vol. 23 (4) October, 2019

ISSN(e): 24086851; ISSN(Print); 1119944X

http://journal.aesonnigeria.org

http://www.ajol.info/index.php/jae

Email: editorinchief@aesonnigeria.org

agricultural zones in the two states were considered for the study. Seven (7) LGAs that have recorded high incidence of communal conflicts over the years were purposively selected (4 out of 23 LGAs from Benue State and three out of 13 LGAs from Nasarawa State respectively). Eleven (11) extension blocks with high prevalence of communal conflicts were purposively selected from the LGAs (eight (8) extension blocks from Benue State and three (3) extension blocks from Nasarawa State. Twenty-four (24) extension cells that have experienced recurrent communal conflicts were randomly selected (15 extension cells from

Benue State and 9 extension cells from Nasarawa State). From the list of farm families from each of the cells, 391 farmers (277 farmers from Benue State and 114 farmers from Nasarawa State) were selected through proportionate and random selection using the Taro Yamane formula for determination of sample size.

Primary data were collected with the use of structured questionnaire, interview schedule and focus group discussion which elicited information from the farmers and analysed using both descriptive statistics (frequencies, percentages, mean and Likert-type rating scale) and inferential statistics (Ordered Logit Regression).

The empirical model for the Ordered Logit Regression model estimation used in this study is explicitly specified as follows:

$\operatorname{Prob}(\mathrm{ACij})=\mathrm{Zij} \theta+\mathrm{T} \mathrm{ij}$

Where:

$A C=$ No, Low and High perceived effects of communal conflicts which will take assigned values of 1,2 and 3 respectively.

$Z$ = Vector of explanatory variables;

$\Theta=$ Vector of regression coefficients; and

$\mathrm{T}=$ the error term.

For this study,

$Y=\beta_{0}+\beta_{1} X_{1}+\beta_{2} X_{2}+\beta_{3} X_{3}+\beta_{4} X_{4}+\beta_{5} X_{5}+\beta_{6} X_{6}+\beta_{7} X_{7}+\beta_{8} X_{8}+\beta_{9} X_{9}+\beta_{10} X_{10}+\beta_{11} X_{11}+\beta_{12} X_{12}+u_{i}$

Where:

$Y_{i}=$ Perception Score

$\beta_{0}=$ Intercept

$\beta_{1}-\beta_{12}=$ Parameters to be estimated

$X=$ is the set of explanatory variables.

The independent variables to be used in the model are:

$X_{1}=$ Age (Years), $X_{2}=\operatorname{Sex}\left(\right.$ Male $=1$, Female $=0$ ), $X_{3}=$ Marital status (Married $=1$, otherwise $=0$ ), $X_{4}=$ Level of Education (Years), $X_{5}=F a r m$ size (ha), $X_{6}=$ Access to telephone (Access $=1$, Otherwise $=0$ ), $X_{7}=$ Major occupation (Farming $=1$, Otherwise $=0$ ), $\quad X_{8}=$ House hold size (Number), $\mathrm{X}_{9}=$ Farming experience (Years), $\mathrm{X}_{10}=$ Frequency of extension contact 
Creative Commons User License: CC BY-NC-ND

Abstracted by: EBSCOhost, Electronic Journals Service (EJS),

Google Scholar, Journal Seek, Scientific Commons,

Food and Agricultural Organization (FAO), CABI and Scopus
Journal of Agricultural Extension

Vol. 23 (4) October, 2019

ISSN(e): 24086851; ISSN(Print); 1119944X

http://journal.aesonnigeria.org

http://www.ajol.info/index.php/jae

Email: editorinchief@aesonnigeria.org

(Number), $\mathrm{X}_{11}=$ Motorable- roads (Yes=1, Otherwise $\left.=0\right), X_{12}=$ Distance from village to major town $(\mathrm{Km})$, ui= Error term

\section{Results and Discussions}

\section{Farmers Perception on Effects of Communal Conflicts on Extension Services Delivery}

Table 1 reveals that the majority of respondents in Benue State perceived communal conflicts to have high effect on the efficiency of extension services delivery $(\bar{x}=2.43)$. This was closely followed by targeting of extension services $(\bar{x}=2.40)$, timeliness of extension services $(\bar{x}=2.38)$, accessibility of extension services $(\bar{x}=2.37)$, relevance of extension services $(\bar{x}=2.33)$, effectiveness of extension services $(\bar{x}=2.32)$ ) and content accuracy of extension Services $(\bar{x}=2.25)$.

For Nasarawa State, the result presented in Table 1 indicated that most of the respondents perceived communal conflicts to have high effect on accessibility of extension services $(\bar{x}=2.82)$ in the study area. Timeliness of extension services $(\bar{x}=2.78)$, efficiency of extension services $(\bar{x}=2.62)$, effectiveness of extension services $(\bar{x}=2.61)$, targeting of extension services $(\bar{x}=2.47)$, relevance of extension services $(\bar{x}=2.43)$ and content accuracy of extension services $(\bar{x}=2.32)$ were other factors of extension services delivery that were perceived as high effect as a result of communal conflicts. This result implies that famers in Benue and Nasarawa States perceived communal conflicts to have a high effect on extension service delivery in the study area. Furthermore, the pooled result in Table 1 also points to the fact that the majority of the respondents in the study area perceived communal conflicts to have high effects on accessibility of extension services $(\bar{x}=2.50)$. This was closely followed by timeliness of extension services $(\bar{x}=2.49)$, efficiency of extension services $(\bar{x}=2.49)$, targeting of extension services $(\bar{x}=2.48)$, effectiveness of extension services $(\bar{x}=2.41)$, relevance of extension services $(\bar{x}=2.36)$ and content accuracy of extension services $(\bar{x}=2.27)$. This findings suggest that as a result of insecurity, extension services delivery were characterized by inaccessibility, untimeliness, ineffectiveness, and poor targeting of extension services in the study area which have great implication for output, income, food security and poverty alleviation. This result is consistent with the findings of Adelakun, Adurogbangba, and Akinbile (2015) that incessant resource-based conflicts have continued to undermine the impact of agricultural extension services delivery in Nigeria resulting in severe effect on availability of extension services, adoption of improved technology and continued use of adopted technology. 
Creative Commons User License: CC BY-NC-ND

Abstracted by: EBSCOhost, Electronic Journals Service (EJS),

Google Scholar, Journal Seek, Scientific Commons,

Food and Agricultural Organization (FAO), CABI and Scopus

http://eoi.citefactor.org/10.11226/v23i4
Journal of Agricultural Extension

Vol. 23 (4) October, 2019

ISSN(e): 24086851; ISSN(Print); 1119944X

http://journal.aesonnigeria.org

http://www.ajol.info/index.php/jae

Email: editorinchief@aesonnigeria.org

Table 1. Perception of farmers on effects communal conflicts on extension services

\begin{tabular}{|c|c|c|c|c|c|c|}
\hline \multirow{2}{*}{$\begin{array}{l}\text { Factors } \\
\text { Rank }\end{array}$} & \multicolumn{2}{|c|}{ Benue $(n=277)$} & \multicolumn{2}{|c|}{ Nasarawa $(n=114)$} & \multicolumn{2}{|c|}{ Pooled $(n=391)$} \\
\hline & & & Mean $(\overline{\mathbf{x}}$ & Rank & & $(\bar{x})$ \\
\hline Accessibility of Extension Services & $2.37^{*}$ & 4 & $2.82^{*}$ & 1 & $2.50^{*}$ & 1 \\
\hline Timeliness of Extension Services & $2.38^{*}$ & 3 & $2.78^{*}$ & 2 & $2.49^{*}$ & 2 \\
\hline Effectiveness of Extension Services & $2.32^{*}$ & 6 & $2.61^{*}$ & 4 & $2.41^{*}$ & 5 \\
\hline Targeting of Extension Services & $2.40^{*}$ & 2 & $2.47^{*}$ & 5 & $2.48^{*}$ & 4 \\
\hline Efficiency of Extension Services & $2.43^{*}$ & 1 & $2.62^{*}$ & 3 & $2.49^{*}$ & 2 \\
\hline Relevance of Extension Services & $2.33^{*}$ & 5 & $2.43^{*}$ & 6 & $2.36^{\star}$ & 6 \\
\hline Usefulness of Extension- & & & & & & \\
\hline Services & $2.25^{*}$ & 7 & $2.32^{*}$ & 7 & $2.27^{*}$ & 7 \\
\hline
\end{tabular}

Source: Field survey, 2017

${ }^{*}=$ High perceived effect

\section{Relationship between Socio-economic Characteristics of Farmers and Perceived Effects of Communal Conflicts on Agricultural Extension Service Delivery}

Table 2 shows that the overall model was statistically significant (LR Chi2 $=50.51, p \leq 0.05$ ) and the predictors included in the model are different from zero. However, sex, marital status, educational status, number of extension contacts, farm size and distance from home to a major town significantly influenced farmers perception of the effects of communal conflicts on extension services delivery in the study area.

Sex of the farmers was positively significant at $5 \%(z=2.03)$. The result implies that male farmers in the study area tend to have a high perceived effect of communal conflicts on agricultural extension services delivery than their female counterparts because of their dominance in farming. This result suggests that high significant nature of male farmers in conflict areas is an indication that they were more associated with conflicts as they are more subjected to usage of the land and Fadama resources that have been the major sources of communal conflicts.

Marital status was negatively significant at $1 \%(z=-2.57)$. This result suggests that those who are not married have low perceived effect of communal conflicts on extension service delivery than their counterparts who are married since they may be less involved in farming activities.

Educational status was positively significant at $5 \%(z=2.11)$. This finding implies that the more educated the farmers, the more rational they are in their decision making and ability to relate any incidence that may affect their farming activities. This implies that education can play a vital role in motivation and facilitation of farmer's adoption and utilization of new agricultural technologies and access to credit facilities that will result in the improvement in farmers' livelihood. Occurrence of conflicts in communities might impede educational development of areas affected by communal conflicts thereby affecting the access to essential services like agricultural extension leading to a high perceived effect of conflicts on agricultural extension service delivery.

Number of extension contacts was negative and significant at $10 \%(z=-1.85)$. It could therefore imply that farmers would have a low perceived effect of communal conflicts on 
Creative Commons User License: CC BY-NC-ND

Abstracted by: EBSCOhost, Electronic Journals Service (EJS),

Google Scholar, Journal Seek, Scientific Commons,

Food and Agricultural Organization (FAO), CABI and Scopus
Journal of Agricultural Extension

Vol. 23 (4) October, 2019

ISSN(e): 24086851; ISSN(Print); 1119944X

http://journal.aesonnigeria.org

http://www.ajol.info/index.php/jae

Email: editorinchief@aesonnigeria.org

extension services delivery in the study area, if numbers of extension contacts are increased. Farmers who are not contacted by frontline extension agents are expected to have higher probabilities of perceived effects of communal conflicts on extension services delivery. This result is supported by Ibrahim, Peter, Zainab and Dahiru (2013) that as a major stakeholder in agricultural and rural development, agricultural extension could be used for understanding the best ways to handle the farmers, identifying conflicts and solutions so as to improve their agricultural production and overall well-being.

Farm size was positively significant at $5 \%(z=2.06)$, which implies that the larger the farm size of the farming families, the probability that they will have high perceived effect of communal conflicts on extension service delivery increases. This finding is consistent with Bolarinwa, Abdulsalam-Saghir and Oyekunle (2013) and Siyum, Kassa, Sisay and Gebremedhin (2015) that land is one of the key resource responsible for most conflicts in the world, thereby, farmers with large farms may possibly suffer greater losses from conflicts than those that have smaller farms. Thus, introduced/new innovations by extension services may not be adopted in conflict prone areas because of the fear of being displaced from the areas during communal conflicts.

Distance from the farming communities to a major town was positively significant at $1 \%$ $(z=4.63)$ indicating that the remoteness of farming communities prone to communal conflicts could lead to limited or lack of access to extension services as well as difficulty in monitoring the quality of service delivery in a more time-efficient way during period of insecurity. This result agrees with Farhat and Hayes (2013) that remoteness of rural communities in Nigeria makes it very difficult for community members to secure access to essential and emergency services during outbreak of communal conflicts.

Based on the foregoing, the null hypothesis which states that no significant relationship existed between selected socio-economic characteristics of the farmers and their perceived effects of communal conflicts on agricultural extension services delivery is rejected and the alternative hypothesis was therefore accepted. 
Creative Commons User License: CC BY-NC-ND

Abstracted by: EBSCOhost, Electronic Journals Service (EJS),

Google Scholar, Journal Seek, Scientific Commons,

Food and Agricultural Organization (FAO), CABI and Scopus
Journal of Agricultural Extension

Vol. 23 (4) October, 2019

ISSN(e): 24086851; ISSN(Print); 1119944X

http://journal.aesonnigeria.org

http://www.ajol.info/index.php/jae

Email: editorinchief@aesonnigeria.org

Table 2. Relationship between selected socio-economic characteristics of farmers and perceived effect of communal conflicts on agricultural extension service

\begin{tabular}{l} 
delivery \\
Variables \\
\hline Sex \\
Age \\
Marital status \\
Educational status \\
Major occupation \\
Household size \\
Farming experience \\
Extension Contact \\
Farm size \\
Access to motorable roads \\
Distance from home to nearby town \\
Access to Telephone services \\
LR Chi2 (12) \\
Prob > Chi2 \\
Pseudo R ${ }^{2}$
\end{tabular}

Source: Field survey, 2017

${ }^{*} \mathrm{P} \leq 0.05$

\section{Conclusion and Recommendations}

The study revealed that farmers perceived communal conflicts to have high effects on accessibility of extension services, timeliness of extension services, efficiency of extension services, targeting of extension services, effectiveness of extension services, relevance of extension services and usefulness of extension services. Sex of the farmers, marital status, educational status, number of extension contacts, farm size and distance from the farming communities to a major town significantly influenced farmers' perception of the effects of communal conflicts on extension services delivery. Government should adopt policies that would tackle the causes and occurrence of communal conflicts in communities in the country so as to reduce the effect of the conflicts on timeliness, effectiveness, efficiency, targeting and usefulness of extension services. Simple information and communication technology components like radio and mobile devices as well as outside broadcast vans should be used by extension agencies to disseminate agricultural information to farmers in insecured areas so as to reduce the effect of communal conflicts on timeliness, effectiveness, efficiency, targeting and usefulness of extension services.

\section{References}

Adelakun O.E., Adurogbangba., B.A. \& Akinbile, L.A. (2015). Socioeconomic effects of farmerpastoralist conflict on agricultural extension service delivery in Oyo State, Nigeria. Journal of Agricultural Extension, 19 (2), 59-70.

Alimba, N.C. (2014). Probing the dynamics of communal conflict in Northern Nigeria. African Researh Review, 8 (1), 177-204. 
Creative Commons User License: CC BY-NC-ND

Abstracted by: EBSCOhost, Electronic Journals Service (EJS),

Google Scholar, Journal Seek, Scientific Commons,

Food and Agricultural Organization (FAO), CABI and Scopus
Journal of Agricultural Extension

Vol. 23 (4) October, 2019

ISSN(e): 24086851; ISSN(Print); 1119944X

http://journal.aesonnigeria.org

http://www.ajol.info/index.php/jae

Email: editorinchief@aesonnigeria.org

Bolarinwa, K.K., Abdulsalam-Saghir. P., \& Oyekunle, O. (2013). Impact of communal violent conflict on farmer's livelihood activities in two agro-ecological Zones of Nigeria. Journal of Agricultural Science, 5(5), 6-14.

Bruce, J. K \& Boudreaux, K. (2013). Land and conflict: Land disputes and land conflicts. USAID Issue Briefs. Retrieved from http://usaidlandtenure.net 10/06/19

Chikaire, J.U., Orusha, J.O., Irebuisi, D.C., Amanze, P.C., \& Asonye, N.C. (2016). Communal clashes/conflicts: Bane of achieving food production and security among farming households in South-East, Nigeria. Journal of Food Science and Technology, 3(2), 65-72.

Farhat, M. \& Hayes, J. (2013). Impact of roads on security and service delivery. Oxford Policy Management, Professional Evidence and Applied Knowledge Services, United Kingdom Retrieved from https://www.assets.publishing.service.gov.uk

Ibrahim, A.A., Peter, M. B., Zainab, .I.A. and Dahiru, H. (2013). Effectiveness of agricultural extension methods in conflict resolution among pastoralists communities in Adamawa State, Nigeria. IOSR Journal of Agriculture and Veterinary Science 6, (3), 01-05.

Kimenyi, M., Adibe, J., Djiré, M., Jirgi, A. J., Kergna, A., Deressa, T. T., Pugliese, J. E., \& Westbury, A. (2014). The impact of conflict and political instability on agricultural investments in Mali and Nigeria. Washington, DC, Africa Growth Initiative,Working Paper 17, 51p.

Mercy Corps (2015). The economic costs of conflicts and the benefits of peace: Effects of FarmerPastoralist conflict in Nigeria's Middle Belt on State, Sector and National Economies. Retrieved from https://www.mercycorps.org/research 22 $2{ }^{\text {nd }}$ November, 2015.

Ojo M.A., Ojo A.O., Odine, A. I. \& Ogaji A. (2014). Determinants of crop diversification among small - scale food crop farmers in North Central, Nigeria. Production Agriculture and Technology, 10 (2), 0794-5213.

Robertson, A. \& Steve, O. (2012). Adapting agricultural extension to Peace building: USA, Report of a Workshop by the National Academy of Engineering. 51p.

Robertson, A. (2013). A new opportunity: Agricultural extension as a peace building tool. United States Institute of Peace. Retrieved from http://www.usip.org/21/01/16.

Siyum, B.A., Kassa, B., Sisay,B. \& Gebremedhin, M.A. (2015). Farmland conflict and its socioeconomic consequences in TahtayQoraro, Tigray, Ethiopia. International Journal of African and Asian Studies,9, 44-55.

Tsado, J. H. (2013). Analysis of adoption of improved rice packages by farmers in Kwara and Niger States, Nigeria. Unpublished Ph.D. Thesis, Federal University of Technology Minna, pp 2427.

Tukur, M.B. (2014) Perspectives on the conflicts between farmers and transhumant pastoralists in Nigeria: Retrieved from http://www.theeagleonline.com.ng 25/05.2015. 